\title{
Freedom to Know Me: The Conflict between Identity and Mennonite Culture in Miriam Toews' A Complicated Kindness
}

Rita Dirks

Ambrose University, Calgary

\author{
"Freedom's just another word \\ For nothin' left to lose." ${ }^{\prime}$
}

In Miriam Toews' A Complicated Kindness (2004), Nomi Nickel, a sixteen-year-old Mennonite girl from southern Manitoba, Canada, tells her story, in episodic chunks of memory, of her short life before being excommunicated from the closed community of East Village. Set in the early I980s, the story details the events that lead up to Nomi's excommunication, or shunning; Nomi's exclusion is partly due to her embracing of the "English" ("That's what people in my town called anybody who wasn't Mennonite"Toews, p. I34) culture through popular, mostly I970s, music and books such as J.D. Salinger's The Catcher in the Rye. Insofar as Toews's novel presents the conflict between the teenaged narrator and the patriarchal, conservative Mennonite community, the book represents Nomi's position at the crossroads of negative and positive freedom (Dworkin, 20 I 5 ). The sarcastic, satirical Nomi must, in this Bildungsroman, resolve the dialectic of her very identity: the negative freedom of No Me (she declares herself to be "Nomi from Nowhere" (Toews, p. 56) incurred through shunning, where

I Lightfoot, Gordon, "Me and Bobby McGee," If You Could Read My Mind (ı970, Warner Bros.).

How to cite this book chapter:

Dirks, R. 202I. Freedom to Know Me: The Conflict between Identity and Mennonite Culture in Miriam Toews' A Complicated Kindness. In: Jonsson, H., Berg, L., Edfeldt, C. and Jansson, B. G. (eds.) Narratives Crossing Borders: The Dynamics of Cultural Interaction. Pp. 33-50. Stockholm: Stockholm University Press. DOI: https://doi.org/IO.I6993/bbj.b. License: CC-BY 4.0 
she literally has "nothin' left to lose," or the positive freedom of Know Me, insofar as having an identity outside of her community. Nomi's excommunication leaves her invisible or erased in East Village; there is no interference from anyone-everyone remains passive in light of her excommunication-a circumstance which gives her a kind of negative freedom; yet, inadvertently it becomes here positive freedom as she gains self-understanding and becomes a writer.

Nomi is a representative of the second generation of Mennonite Canadians that finds itself on the periphery of at least two cultures. At first reading, because of the engaging satirical tone of the teenage narrator, the novel presents itself as a condemnation of the religious fundamentalism of her own people. Certainly, the author's powerful iconoclastic work is fuelled by her own intimate knowledge of the Mennonite way of life, for Toews lays bare the punishing mores of that culture in a young protagonist's formative experiences. Yet, that is not the whole story. My chapter, then, places on view the tension between Nomi's identification with her own culture and the disowning of it, as it disowns her because she also participates in the culture outside of it. Such a position is at once a predicament and a blessing; writers and marginalized intellectuals are often in this same situation and must negotiate their place within and without such communities. As such, Nomi represents the plight of the second wave of Mennonite writers in Canada. Di Brandt, a poet who rose to prominence in the I980s, writes:

I think it's important for us to remember ... how difficult it was for most of us to become writers in the 1980 os, how much resistance we needed to put up to the many internal community forces that were trying to control the narrative identity of Mennonites. (Brandt)

Shunning in some shape or form was a common experience for these writers because they offered a different voice than the official "schmock bliewe" ${ }^{2}$ one. They needed to overcome resistance, or cultural, symbolic, and identity borders, in order to give voice

${ }^{2}$ Mennonite Low German for "remaining” or "abiding obedient," or painting "pretty" pictures only when telling a story. "Schmock bliewe," literally "remaining pretty" or "nice," along with "ontlich," meaning "obedient" 
to their distinct Mennonite experiences. Mennonites, historically, have crossed many a geographical border to flee persecution; much of their oral and sometimes published narratives in the past involved stories of faith, martyrdom, and escape from oppressors. Such narratives were always controlled, before the event of Canadian Mennonite writers getting published in the twentieth century. Toews, in A Complicated Kindness, places the act of shunning on view as an invisible enforced border between Nomi and her community; in East Village she becomes a non-entity, a ghost, but she begins to write, in her own voice.

Notably, A Complicated Kindness begins with absences and shunnings: "The furniture keeps disappearing," and "half of our family, the better-looking half, is missing," symbolizing the loss of stability of the Nickel family within their community, causing Nomi to question her own relationship between self and Mennonite community and the larger community of city, country, and world (Toews, p. I). At the beginning of the novel, Nomi does not know that she is about to be shunned herself, and the only other remaining family member, her father Ray, is selling the furniture in order to leave East Village as well. In this novel of becoming, Nomi becomes a writer, for on the first page of $A$ Complicated Kindness, she is working on an assignment for her English teacher, which, in fact, becomes the novel. Mr. Quiring expects her to write an essay about "The Flight of Our People," in the vein of the official narrative wherein her ancestors escaped Russia, "fleeing in the middle of the night, scrambling madly to find a place, any place, where they'd be free" (Toews, p. I48). Nomi, instead, and in a sinister parallel, writes of her sister and mother, leaving in the middle of the night, after they had been excommunicated, toward a dubious freedom.

As a bourgeoning writer, Nomi navigates between the politics of belonging/not belonging, between memory, history, her communal and familial identity, and her own individual agency within and without. Yet, the novel presents no easy binary; by the end of the novel, completely alone, we do not know where Nomi will go; before the final pages she dreams of going to New York and

or "observing decorum," were words that many of us heard as Mennonite children. 
Winnipeg. The truth is more complicated than Nomi "find[ing] salvation in the city and damnation in a small town" (Loewen, 20I 5, p. 45). Worthy of note here is a recent volume edited by Robert Zacharias, After Identity: Mennonite Writing in North America (2015), which suggests that we live in a post-identity age. Yet, as both Toews and the contributors to After Identity indicate, it is not that simple. In this after-identity age, Nomi's search resonates with readers in Canada more than ever, even if one considers the awards A Complicated Kindness has received (The Governor General's Award), translations into other languages, and copies sold. For the purposes of this chapter I utilize Zacharias's meaning of the word "after" as denoting a pursuit of or still seeking or owning a complicated identity.

\section{Mennonites (Writing) in Canada}

As I address the topic of the conflict between Mennonite culture and Canadian society, I must call attention to the fact that Canada does not have one readily identifiable mainstream culture; to begin with, it is First Nations, then English and French, and, since the Multiculturalism Act of I988, at least officially, it celebrates the plurality of ethnical cultural production. However, most Canadian writers still publish in one of the official languages or else remain obscure, incidental, and narrowly ethnic. For example, Reuben Epp (1920-2009), who has chosen to write his poetry and short stories in Low German, the oral language of the Mennonites, reaches only a "restrictive" audience (Levertov, I998, p. 482). E.D. Blodgett also writes of this dilemma:

The paradox for . . . immigrants whose native language is not English, is that if access to agency appears offered by English, it carries a high cultural price. If some immigrant writers continue to write in their national languages, such as Ukrainian and Hungarian, their presence in Canada and their bearing on the literary system of Anglophone writing is limited, inasmuch as they have chosen separation or marginalization. If they choose English or French, as . . . most immigrants have done, they acquire, in many cases, the insights of integration, but run the risk of being read without full understanding by the people of other cultures of their difference and their challenge. (2004, p. 230) 
Canadian Mennonites are also distinct from other ethnic groups living in Canada in yet another way: They do not belong to one parent nation state in Europe or elsewhere in the world. While Italian, Ukrainian, Russian, and Swedish immigrants to Canada have a point of reference in their ancient homes in Europe, Mennonites have no such home.

Toews obviously writes in English, yet she finds a way to include her Mennonite heritage using Low German phrases, often untranslated, throughout the novel. In her own way, she evades the two pressures to conform: She does not write in one of the official Canadian languages exclusively, yet, at the same time, she resists appropriation by the Mennonite tradition, however, not without bearing out the tension in the inclusion of both. In combining the two languages, she expresses and safeguards her own heterogeneous identity, her own voice. If Toews had simply wanted to write a novel disparaging the Mennonites, it would have been easy to bash the backward religious conservative folk that she left behind. However, in an interview, she admits, "For the longest time I didn't think that all that Mennonite stuff affected me the way that it did. I felt I could somehow just move away from the community and escape and be fine. And then I realized that it gets under your skin and settles in there" (Wiebe, 2007 , p. I2I). Toews continues to live in the creative tension between having left the Mennonite fold physically, yet also coming to terms with Mennonitism in her novels.

Certainly, there is an added tension in the form of conflict between Mennonite writer and Mennonite community because, for most of its history, a strict ancient binary has separated art and worldliness in that tradition. Mennonites were instructed to be a separate people by their founder Menno Simons (I496-I 56I) who said, "we must not love the world and the things therein, nor conform to the world" (Simons, p. IOI). The separatist mentality arose because of their dissenting beliefs, as they broke away from the Catholic Church-professing pacifism, adult baptism, a literal reading of the Bible, separation of church and state-and was reinforced by sustained persecutions and forced migrations. The "theological separation" followed by a "cultural separation" encourage Mennonites to "acquire ... a separatist psychology," or 
an us/them mentality (Epp, I974, p. 20). Cornelius J. Dyck writes that often for Mennonites, when they began to settle in North America,

non-Mennonites were a threat to the faith, necessitating withdrawal from the "world" with its temptation and sin. Marriage with non-Mennonites, for example, was strongly opposed and sometimes led to excommunication because the new partner was considered to be worldly and an outsider, usually designated by the terms Weltmensch [man of the world-my translation] and Engländer [the English-my translation] respectively. (Dyck, I967, p. 292)

Even in the nineteen eighties, Toews portrays marriage between close relations as common practice: "Trudie and Ray [Nomi's parents] are second cousins. Which makes me and Tash [Nomi's sister] not only sisters but also third cousins" (Toews, p. 6). In the novel, intercourse with non-Mennonites is discouraged, and intermarriage within the Mennonite settlements is common, to warrant minimal integration and much resistance to acculturation in Canada and elsewhere. By the same token, art is "worldly," belonging to "them," outside of the Mennonite milieu.

East Village represents a kind of a state within a state, or the historical situation of Mennonite settlements within larger countries, as in Russia from the end of the eighteenth to the end of the nineteenth centuries and in Canada from the late nineteenth century onward. A unique picture of colonialism emerges as it concerns the Mennonites: Through Tsarina Catharine II's invitation they settled in southern Russia, now Ukraine, to develop "the lands vacated by the Turks" (Dyck, p. I 26). Mennonites started to come in the I780s, partly because "Russian colonial policy at that time aimed at a complete separation of all foreigners from the native population," a policy that "appealed to the Mennonites" a great deal (Dyck, I967, p. I27). Mennonites lived in colonies in Russia, and then again in separate communities within Canada.

Because Mennonites cannot refer to a single country as their ancestral home but have fled several, this homelessness and group trauma from persecutions strengthen their bond and exclusivity; they have a shared sense of continuity instead of a shared culture of origin. Mennonites have always shown a resistance to subordination, have received permission not to assimilate-no 
military service, their own religion, language and schools-and have moved on if such permissions were terminated, notably in Russia. While early Canadian writers might have had the difficulty of distinguishing their own writing in Canada from a continuation of say English or German writing, Mennonites had no indigenous literature arising from what could be called a mother country. When Homi Bhabha (Bhabha, I994, p. xi) writes of his position as someone who lives and writes "within a world-system whose major economic impulses and cultural investments are pointed in a direction away from you, your country or your people," and that "such neglect can be a deeply negating, oppressive and exclusionary," there is no such parallel experience with the Mennonites. Certainly, Mennonites as a people have experienced persecution and oppression, but they have, by and large, chosen to exclude themselves and migrate to the next country. In other words, they do not concern themselves with exclusion and lack of cultural investments from the world; on the contrary, they want to be left alone.

\section{Toews's Mennonites}

Paradoxically, the Mennonites, as represented by Toews in $A$ Complicated Kindness, who have escaped past persecutions because their beliefs were different from mainstream religions, oppress individuals within their own community who are different from the clan. The Nickel family lives in East Village as if inside another larger, even hostile, country, under the authority and strict observation of tyrannical leaders. Ervin Beck writes of "the tragic outcome of communitarianism that yields too much authority to the fanatic leadership of a few-usually patriarchal-leaders" and that "enforced conformity leads to oppression" (Beck, I998, p. 544). Mennonite hegemony has the right to exercise the rite of excommunication, as Toews's novel demonstrates through Nomi's and her sister's, and countless others', shunnings.

The totalitarian regime that controls individual behaviour still defines the colony: Nomi compares the head minister of East Village, dubbed The Mouth, or "the Über-Schultz," to "Moammar Gaddafi or Joseph Stalin. You fall into line or you fall" (Toews, p. Io). The mechanism of exclusion is operated by The Mouth 
and a few elders who subordinate the villagers's identities to their own will:

They threw my mother out, gave her the old heave-ho. The term is excommunicated... . The Mouth and the other elders and the deacons and the lay people had met for a good seven or eight minutes before they decided that Trudie was history. (Toews, p. I 89)

The laws of shunning do not allow for members of the community to speak to or eat with or in any way associate with the shunned. The patriarchal nature of the control is exemplified through the deliberate choice in shunning women: pre- and extramarital sexual activity is punished severely in East Village; yet, it is Nomi who is excommunicated, not her boyfriend Travis, and, similarly, Tash is shunned but not her boyfriend Ian, and Trudie is given "the old heave-ho," but not Mr. Quiring.

The homelessness of Mennonites globally in a strange way reinforces the 'unhoming' or making of their own members, the ones who fall out of line, homeless. Shunning destroys Nomi's family life and her family home. Her mother, older sister, and eventually her father desert East Village one after the other, leaving the sixteen-year-old alone. Toews describes a kind of "homelessness" for Nomi that Edward Said refers to in his autobiographical Out of Place (I999) that "begins at home," a feeling of displacement and not quite identifying oneself with the place where one is (Winnett, 2004, pp. 354, 352). Nomi had a home and a family and a community in her hometown until she was thirteen. A Complicated Kindness begins with the young girl trying to cope with her losses, as she, at the same time, becomes a teenager and seeks the freedom to know herself. Nomi lets the title of one of her favourite albumsthe Rolling Stones' Exile on Main Street—speak unambiguously; her taste in music betrays her state of exile at the centre of her community (Toews, p. 48). The shunning of her family makes Nomi an outsider in her very own society, among her own people.

\section{Toews and the Situation of Mennonite Writers and (Fictional) Readers}

Inasmuch as A Complicated Kindness is based on autobiographical material, Toews finds freedom in leaving her Steinbach home 
and writing in English. Nomi's situation reflects the many obstacles that a Mennonite writer usually faces, before he or she leaves. Harry Loewen points out that there was some "creative literature established by Russian Mennonites" before their immigration to Canada (1992, 52). David Arnason also speaks of the "tradition of writing" that had "developed among the Mennonites in Russia in the late nineteenth century (1992, p. 213). However, until recently, and more specifically since Rudy Wiebe's publication of his first novel Peace Shall Destroy Many (1962), and then the flourishing of the Mennonite arts in Canada in the I980s, Mennonites have not been known for their independent artistic output. The I980s were a turning point for Mennonite literature: Di Brandt, Patrick Friesen, Audrey Poetker, Sandra Birdsell, just to name a few, reclaimed their right to creative freedom. The decade marks the end of the "repression of the artistic impulse," as Maurice Mierau writes in his essay "Rebel Mennos Move into the Arts" ( $1987-88$, p. I8). In I996, Di Brandt, in the foreword to her collection of essays entitled Dancing Naked, writes about "how long it took [her] to recover from the trauma of breaking through the strict codes of separatism and public silence [she] grew up with in the Mennonite community of south-central Manitoba, and how difficult it was to actually break centuries-old taboos against self-expression and art-making” (Wiebe, 2007, p. I I6). "The strict codes of separatism" are giving way to participation in the life of higher education or artistic production. "The major causes," Brandt names about the old ways dying, "are television, radio, and travel, all of which break down the community's essential separateness from outside society" (Mierau, I987-88, p. I9). From within, Mennonite literature "is one of the ways of destroying that separateness. . I'm helping to kill it (Mennonitism) off," she says in an interview with Mierau (1987-88, p. 19). Fittingly, Toews demonstrates the reality this influence via (banned) music and books in her novel.

Miriam Toews, in the twenty-first century, breaks through the rigid codes and the taboos of silence in her own way in $A$ Complicated Kindness. In the beginning of her novel, the separation from the world expresses itself in the very prohibitions against literature, modern music, and television. Even in East Village people got televisions, although, in Nomi's words, "TVs were . . . on Menno's shitlist, at least they would have been if he's been 
around when they were invented. We didn't get one until one of our cousins who was both a first and second cousin to us, and possibly an uncle and future in-law, was on 'Reach for the Top" (Toews, p. I 5). Nomi writes about her confusion regarding what is allowed in East Village and what is not:

There were so many bizarre categories of things we couldn't do and things we could do and none of it has ever made any sense to me at all. Menno was on a cough-syrup binge when he drew up these lists of dos and donts and somehow, inexplicably, they've survived and are now an integral part of our lives. (Toews, p. I3).

In terms of books, they are allowed to read J.R.R. Tolkien and C.S. Lewis, for their Christian message, but not books much read in the '8os like those by Hesse or Nabokov. Nomi exclaims that "[I]f [she] is forced to read one more Narnia series book [by C.S. Lewis] [she]'ll kill [her]self" (Toews, p. 6).

Trudie, Nomi's mother, loves to read as well: "My sister and I went to school in the morning and my mom would stand in the doorway in her nightgown and say goodbye ... and we'd come home at four o'clock in the afternoon and she'd still be in her nightgown, but on the couch, with her finger as a marker in the books, saying . . . don't tell me it's after four already" (Toews, p. 8). In Nomi's words, Trudie was "[h]alf in the world, half out" (Toews, p. I2). Trudie also loved music; she sang loudly in church but also

hid her records in Tash's old toy box in the basement. One time when Tash was around ten, Tash called up The Mouth and told him she's found one of Trudie's Kris Kristofferson's eight-tracks and she was very afraid she was about to listen to it and The Mouth said okay, now, calm down, pray with me. Take the ... item and put it in a paper bag. Staple the bag closed and bring it to me here, to the parsonage, and we will deal with it together. Satan is tempting you, do you know that? Yes, said Tash. ... She and her friends, who were listening to the whole thing, rolled around on the floor, killing themselves laughing. . . . Later that day The Mouth came over to talk and pray with Trudie about her fondness for guys like Kristofferson and Billy Joel. He told her that in his dictionary bell comes after rock ' $n$ ' roll'. (Toews, p. I 2) 
Instead of reading and listening to popular music, adult women in East Village are relegated to the church basement: "She [Trudie] was supposed to do all sorts of stuff at church, ... generally get her ass in humble helping gear" (Toews, p. 9). They are expected "to spend a lot of time there [in the basement]. If they don't, they go to hell"; this was particularly hateful to Trudie who was a free spirit: "She got into trouble for throwing a couple of romance novels into a barrel headed for Nicaragua" (Toews, p. 9). Trudie was a misfit in East Village; she "hated thinking of herself as a citizen of the world's most non-progressive community" (Toews, p. 32). The women in the Nickel family, and for the most part Ray as well, find their heteroglossic identity in the intersections of various cultures: American and Canadian TV and (forbidden) books, as well as their own twisted Mennonite humour. Nomi's parents use Low German phrases in a playful joking way, for, in this instance, Plautdietsch represents the colourful language of the people, of jokes, an instance where Low German is just the right word or words to express something specifically Mennonite. Among the Nickels, the language becomes one of laughter, or subversive humour.

Nomi and Tash and other teenagers in A Complicated Kindness read much and freely: The Joy of Sex, Alice Munro's Lives of Girls and Women, Seventeens, Günter Grass, Alexander Solzhenitsyn, Dostoevsky's Notes from Underground, Kahlil Gibran's The Prophet, Herman Hesse's Siddhartha, Henry Miller's Tropic of Cancer, and Kafka. These Mennonite teenagers want to know what is happening in the larger world; they want to be in the know. However, in school, for their English assignments, they are "not allowed to write about Kahlil Gibran, ... Holden Caulfield, Nietzsche, ... Nabokov" (Toews, p. I 52 ). The person who enforces the "oddball" school curriculum is also The Mouth who after "the purges," or declared non-compliance with standard provincial guidelines, "took over everything" (Toews, pp. I3, Iо, I3). Nomi tries to write objectively on a Mennonite topic: "I had once tried to hand in an essay entitled 'How Menno Lost His Faith in the Real World (Possible Reasons)', which was similarly rejected" (Toews, p. 69). "So what should I write about?" asks Nomi after her latest essay for English "got panned by Mr. Quiring” 
(Toews, p. I 52). Everything of interest to a growing mind and anything that might challenge the imagination are forbidden. The Mennonites in authoritarian positions in East Village perceive literature as an outside threat to their ways of being. "We're a national joke," Tash would say, "Everybody mocks us and the more they do the more The Mouth goes: We won't give in! . . . We'll ban more books! We'll burn more records!" (Toews, pp. 70-7I). As her response to the intellectual prohibition, Tash hitches rides to the city and, scandalously, gets a city library card; she brings "home books not by Billy Graham [n]or about the Sugar Creek Gang" but, among other books, pamphlets about communism" (Toews, p. I I9). Soon after, Nomi writes, "my mother told me that Tash had become an atheist"; "Oh my God, I whispered .... That fucking library card, man" (Toews, pp. I64, I65).

\section{Mennonites and Art}

"Art," according to Brandt, has been unacceptable to many Mennonites because it challenges and criticizes the one [authoritarian] voice in the community" (Mierau, I987-88, p. I9). And worse, according to Patrick Friesen, in "the traditional Mennonite view," art "hampered your pursuit of salvation" (Mierau, I 987-88, p. 20). "'They don't understand,' continues Friesen, 'that art can be a life-enlightening thing"” (Mierau, ı097-88, p. 20). Closed communities tend to be afraid of imaginative and intellectual inquiry (Wiebe, I980, p. I 50). For centuries, they have been "culturally barren islands of devoid of a genuine life and artistic activity" (Reimer, I980, p. 22I). The only type of writing that is acceptable among Mennonites is of the "rigidly didactic" and "sweetly pious" kind (Reimer, I980, p. 222). For her assignments in school, Nomi is encouraged to write about "The Flight of Our People"-kind of essays that delineate the great trek of Mennonites escaping Russia to come to Canada. Instead, Nomi' story, which she does hand in at the end of the novel, also entitled "The Flight of Our People," is about her family, fleeing East Village. Mennonites love to tell stories about suffering, escape, exodus, and martyrdom in the past; Toews, through Nomi, rewrites this well-known Mennonite master narrative of migration journeys when she writes of the trauma within their own communities. 
Toews's novel offers a condemnation of the religious fundamentalism of her people through the voice of the intelligent, sad, and sarcastic Nomi who places on view the unbending age-old traditions through the perspective of a teenager who questions such customs. Patrick Friesen, writing of the real Steinbach community where both he and Toews grew up, refers to it as "a bloody concentration camp" with "no culture" and where "they treat people as objects and don't see each other as humans first" (Loewen Reimer and Tiessen, I98 5, pp. 245, 246). For Friesen, "if the Mennonite religion takes hold, a person may never become an artist" because of what the poet terms the "totalitarian" effect of the community on the artistic individual. "For me as an artist," he writes, "the religion was a dictatorship" (Mierau, I987-88, p. 20). Toews, in an interview with Rachael Kohn, talks about growing up in Steinbach as well: "There was suspicion of education. You know certainly not supportive of intellectual life. There was just no room for the artist or for the subversive in that type of community. ... we were restricted as to the types of books that we could read, and the music and that sort of thing" (Kohn, 2005). For Friesen and Toews, these restrictions would have stifled them as writers and, in order to remain such, they had to leave Steinbach.

In an interview three years after the publication of $A$ Complicated Kindness Toews says that her novel is "not an indictment or a criticism of the faith of the Mennonite people, but of the fundamentalism" (Wiebe, 2007, p. I04). She criticizes religious fundamentalism but not faith itself; in the end of the novel, her protagonist says: "East Village has given me the faith to believe in the possibility of a happy family reunion someday. Is it wrong to trust in a beautiful lie if it helps you get through life?" (Toews, pp. 245-246). Nomi's faith remains as a beautiful lie or fiction or literature in the form of her own traumatic yet hopeful story. Nomi, about to pack up the car that her father leaves for her, ponders all the good things, or the things she will miss, about East Village. She is the last of her family to leave East Village, if indeed she does (the ending is not clear). As she tells her guidance counsellor earlier, she does love this place (Toews, p. 5). Nomi finds herself torn between the love she has for her hometown where she was happy with her family and, as much as she expresses her 
desire to leave the place throughout the novel, the pain of being cast aside by the community. Toews does not resolve the dialectic between belonging at the cost of personal freedom and freedom without roots. For Nomi, identity remains hybrid, not in the least found in questioning the assumptions and practices of her community. As is perhaps fitting of a sixteen-year-old, her identity is not static, but confirmed, destroyed, in process, an amalgam of acceptance and rejection (of self and by others).

Nomi has, however, developed into a writer. The whole novel can be seen as Nomi's submission of the final assignment to Mr. Quiring. In fact, Nomi hands it in at the end of the book: "for the way things could have been. Which is what I'm calling my assignment" (Toews, p 242). The assignment is Nomi's novel and her own, not "schmock bliewe" assessment of her people. She does not hold out much hope that Mr. Quiring will like it or even read it to the end, but she writes the story anyway. With her final assignment she includes Mr. Quiring's own blackmail letter to Trudie (which Nomi finds in a dresser drawer after her mother leaves) that threatens to "expose" her mother to the community as an adulteress if she refuses to meet with him. Nomi understands some of the reasons Trudie leaves; this realization is also the teenager's understanding through disillusionment that her parents' love was not perfect and that in this patriarchal community Trudie has no voice. Mr. Quiring's story would be believed without question, leaving Trudie powerless and silent. In this final act, Nomi exposes the phoniness á la Holden Caulfield and hypocrisy of the male authority in her community.

As observed above, Canadian Mennonite artists have frequently had to leave their Mennonite communities in order to be artists. Often, they have found support from mainstream Canadian folk and organizations. Inside conservative Mennonite circles, one would expect a negative reception of A Complicated Kindness. Indeed, Toews herself says: "There were angry people who said it's all lies. . . . This is what I expected to happen. What I did not expect was the incredible support that was out there" (Wiebe, 2007 , p. I I 8). In I992, Rudy Wiebe, after the publication of his Mennonite novels between I962 and the early nineties, remarks that the "encouragement" he had "received has very rarely come 
from Mennonites. It has certainly never come from official circles" (Tiessen and Hinchcliffe, I992, p. 229). When Natasha G. Wiebe asks Toews why there was more favourable response to Toews' novels than to Rudy Wiebe's "Mennonite" novels, and wonders: "Is it because most of the Mennonites are now assimilated (within Canadian culture], Toews answers: "I think that is a big part of it, absolutely. Times change, people change" (Wiebe, 2007, p. I I9). When Rachael Kohn asked Toews in 2005 about the Mennonite reaction to her books, she says:

first of all, the Mennonite culture,... it's tight-lipped, it's a silent disapproval. And I'm used to that, I've had that all my life, so it doesn't bother me. But . . . it's not even the most conservative group of Mennonites in my community that disapprove of the books, it's a type of individual, and they're everywhere, that has no sense of humour, doesn't like self-analysis, doesn't understand that you can be critical of something and love it at the same time. (2005, no page)

Toews continues in the same interview: "Some say it [the novel] is harsh, it's ugly to read, and there is truth to it, you know we have to look at this about ourselves, this damage that we're doing basically to families, with the whole shunning thing" (Kohn, 2005, no page). To be sure, Mennonites in Canada are in the process of re-examining their continuation of obsolete, damaging practices and attitudes.

Nomi is consigned to the marginal realm within her community by its elders; her loneliness, conduct, and rootlessness are the result of losing her mother and sister to the Mennonite practice of shunning. Toews herself still rages "against that type of hypocrisy and self-righteousness and arrogance and cruelty" as expressed in the novel by The Mouth and Mr. Quiring (Kohn, 2005, no page). Martin Kuester also writes of "the inhumanity of a provincial, strict Mennonite community" and "the callousness of these male dominated communities" (Kuester, 20I I, no page). Kuester, however, does not see Nomi as "completely powerless"; "she can take her life into her own hands," even with her whole family gone and having been shunned herself, because she has found her voice as a writer, as a storyteller, despite the abuse she experiences at the hands of men in authority in East Village (Kuester, 20I I, no page). 


\section{Towards a Conclusion}

Recently, Hildi Froese Tiessen recalls a "strategic planning session" at Conrad Grebel University College in Waterloo, Ontario, where an unnamed "committed Grebel alumnus" urged to "support and encourage those academics ("he was referring exclusively to historians and theologians") who are committed to the task of telling our story, .. adding, without an ounce of humor, 'otherwise Miriam Toews will have the last word"' (Tiessen, 2008, p. 46). I hope she does, for literature destabilizes the tidy singular meanings of a particular culture, in this case of the Mennonite tradition, and speaks freely from the rich margins of heterogeneous identity. As Nomi navigates towards freedom in A Complicated Kindness, she speaks, in her own satirical, sad, beautiful voice, saying Know Me, as I am. The conflict between the teenager-writer and Mennonite patriarchal fundamentalism, had it been resolved in its favour, would have resulted in No Me, or a silenced unfree person. From the beginning, Nomi says to one of her teachers, "I just want to be myself .... I want to be free" (Toews, 48). Through the very music and books that were banned in East Village, she finds the language and freedom to express herself and to know herself. In becoming banned or shunned Nomi finds herself with "nothing left to lose" (Toews, p, I 89); unintentionally, after everything and everyone are taken from her, the only option that remains is her freedom to write, to form her own identity, or a positive freedom. Nomi rewrites the controlling Mennonite narrative as she hands in her own "The Flight of Our People." Ironically, Mennonite culture, so full of tales of having no permanent home and crossing a variety of borders, makes its own undesirables, among them artists and writers, homeless. Yet, Nomi finds herself and her home among writers.

\section{References}

Arnason, D. (1992). "A History of Turnstone Press," in H. Froese Tiessen and P. Hinchcliffe (eds.) Acts of Concealment: Mennonite/s Writing in Canada. Waterloo: University of Waterloo Press, pp. 2I 2-22.

Beck, E. (I998). "The Signifying Menno: Archetypes for Authors and Critics," Mennonite Quarterly Review, 72(4), pp. 529-47. 
Bhabha, H. G. (1994). The Location of Culture. London \& New York: Routledge.

Blodgett, E.D. (2004, 2003). Five Part Invention: A History of Literary History in Canada. Toronto: University of Toronto Press.

Brandt, Di. (2016). "Di Brandt: Recommended Reading List.” Blog. University of Manitoba Press. March 23, 30I6. Available at https:// uofmpress.ca/blog/entry/di-brandt-recommended-reading-list (Accessed: February 27, 2018).

Dworkin, G. (2015). "Positive and negative freedom." In R. Audi (ed.), The Cambridge Dictionary of Philosophy. 3 rd edn. Cambridge: Cambridge University Press. Available at: http://ezproxy.lib.ucal gary.ca/login?url=https://search.credoreference.com/content /entry/cupdphil/positive_and_negative_freedom/o? institutionId =26I (Accessed 27 February 20I8).

Dyck, C. J. ( I 967). "Mennonites in the North American Environment," in Dyck, C.J. (ed.) An Introduction to Mennonite History. Scottsdale: Herald Press.

Epp, F. H. (1974). Mennonites in Canada, I786-I920: The History of a Separate People. Toronto: Macmillan.

Kohn, R. (2005). The Spirit of Things: 5 June $2005-A$ Complicated Kindness. ABC Radio National, Australian Broadcasting Corporation. Available at http://www.abc.net.au/rn/relig/spirit /stories/sI $380744 \cdot h t m l$ (Accessed 20 October 20II).

Kuester, M. (20II). "A Complicated Kindness-The Contribution of Mennonite Authors to Canadian Culture.” Reimer, G. (trans.). CMW Journal 3(2). Available at http://www.mennonitewriting .org/journal/3/2/ (Accessed 8 June 20II).

Levertov, D. (1998). "The Migrant Muse: Roots and Airplants," Mennonite Quarterly Review 72(4), pp. 48 I-89.

Loewen, H. (1992). “The Beginning of Russian-Mennonite Literature in Canada: With a Focus on Gerhard Loewen (I 863-I946), Poet and Teacher," in H. Froese Tiessen and P. Hinchcliffe (eds.) Acts of Concealment: Mennonite/s Writing in Canada. Waterloo: University of Waterloo Press, pp. 52-70.

Loewen, H., Reimer, M. and Teissen, P. G. (I985). "The Poetry of Patrick Friesen and David Waltner-Toews," in Loewen, H. and 
Reimer, A. (eds). Visions and Realities: Essays, Poems, and Fiction Dealing with Mennonite Issues. Winnipeg: Hyperion Press, pp. 234-53.

Loewen, R. (20 I 5). "A Mennonite Fin de Siècle: Exploring Identity at the Turn of the Century," in Zacharias, R. (ed.) Exploring identity at the Turn of the Twenty-First Century. Winnipeg: The University of Manitoba Press, pp. 37-5I.

Mierau, M. (I987-88). "Rebel Mennos Move into the Art," in Midcontinental, pp. I8-23.

Reimer, A. (I980). The Russian-Mennonite Experience in Fiction, in Loewen, H. (ed.) Mennonite Images: Historical, Cultural, and Literary Essays Dealing with Mennonite Issues. Winnipeg: Hyperion Press, pp. 22 I-235.

Simons, M. (1984, 1956). "The New Birth," in The Complete Works of Menno Simons, c. I496-I 56I. Verduin, L. (trans.) and Wenger, J.C. (ed.), with a biography by Bender, H.S. Scottsdale/Kitchener: Herald Press.

Tiessen, H.F. (2008). "Mennonite/s Writing: State of the Art?," The Conrad Grebel Review 26(I), pp. 4I-49.

Tiessen, H. F. and Hinchcliffe, P., eds. (I992). Acts of Concealment: Mennonite/s Writing in Canada. Waterloo: University of Waterloo Press.

Toews, M. (2004). A Complicated Kindness. Toronto: Vintage.

Wiebe, D. (1980). "Philosophical Reflections on Twentieth-Century Mennonite Thought," in Loewen, H. (ed.). Mennonite Images: Historical, Cultural, and Literary Essays Dealing with Mennonite Issues. Winnipeg: Hyperion Press, pp. I49-164.

Wiebe, N. G. (2007). "'It gets under the skin and settles in': A Conversation with Miriam Toews," The Conrad Grebel Review 26(I), pp. I03-I 24.

Winnett, S. (2004). "Writing in Place: Edward Said's Constructions of Exile," Zeitschrift für Anglistik und Amerikanistik 52.4, pp. $53 \mathrm{I}-365$. 